\title{
Correction
}

\section{San Martín, C., Correction: Latest Insights on Adenovirus Structure and Assembly. Viruses 2012, 4, 847-877.}

\section{Carmen San Martín}

Department of Macromolecular Structures, Centro Nacional de Biotecnología (CNB-CSIC), Darwin 3, 28049 Madrid, Spain; E-Mail: carmen@cnb.csic.es; Tel.: +34-915855450; Fax: +34-915854506

Received: 19 December 2012 / Accepted: 19 December 2012 / Published: 19 December 2012

It has come to my attention that my article "Latest Insights on Adenovirus Structure and Assembly" (Viruses 2012, 4, 847-877) [1] contains an inaccurate statement.

On page 864, the caption for Figure 7 reads: "There are four potential cleavage sites in pTP but they have not been experimentally verified". However, three of these sites have been experimentally confirmed in vitro using recombinant AVP and pTP, as described in Webster A, Leith I.R., Hay R.T.: Activation of adenovirus-coded protease and processing of preterminal protein. J. Virol. 1994, 68, 7292-7300 [2].

\section{References}

1. San Martín, C. Latest Insights on Adenovirus Structure and Assembly. Viruses 2012, 4, 847-877.

2. Webster, A.; Leith, I.R.; Hay, R.T. Activation of adenovirus-coded protease and processing of preterminal protein. J. Virol. 1994, 68, 7292-7300.

(C) 2012 by the authors; licensee MDPI, Basel, Switzerland. This article is an open access article distributed under the terms and conditions of the Creative Commons Attribution license (http://creativecommons.org/licenses/by/3.0/). 